\title{
KONDISI CURAH HUJAN DAN CURAH HUJAN EKSTREM SAAT MJO KUAT DAN LEMAH: DISTRIBUSI SPASIAL DAN MUSIMAN DI INDONESIA
}

\section{Precipitation and Extreme Precipitation Condition during Strong and Weak MJO: Spatial and Temporal Distribution in Indonesia}

\author{
Anis Purwaningsih ${ }^{1)^{\star}}$, Teguh Hardjana ${ }^{1)}$, Eddy Hermawan $^{1)}$, Dita Fatria Andarini ${ }^{1)}$ \\ ${ }^{1)}$ Pusat Sains dan Teknologi Atmosfer, Lembaga Penerbangan dan Antariksa Nasional. \\ Jl. Dr. Djunjunan No. 133 Bandung 40173. \\ *E-mail : anis.purwaningsih@lapan.go.id
}

\begin{abstract}
Intisari
Propagasi MJO memicu peningkatan aktifitas konveksi yang menyebabkan kenaikan probabilitas hujan. Intensitas hujan dan frekuensi hujan ekstrem saat MJO pada bulan DJF dan JJA di Indonesia dianalisis. Komposit data curah hujan harian tahun 2008-2018 (CHIRPS) dilakukan berdasar kategori tanggal kejadian MJO (kuat dan lemah) pada tiap fase $(3,4,5)$ menggunakan data indeks Realtime Multivariate MJO. Hujan ekstrem dikategorikan berdasarkan intensitas curah hujan diatas presentil 95\%. Hasil menunjukkan MJO kuat Fase 3, 4 dan 5 lebih sering terjadi saat DJF (frekuensi kejadian 50\% lebih banyak dibanding saat MJO lemah). Saat JJA, frekuensi kejadian MJO kuat dan lemah tidak berbeda signifikan. Saat DJF, di Indonesia bagian barat terjadi peningkatan intensitas hujan saat MJO kuat Fase 3 dan 4. Di Indonesia bagian timur, peningkatan curah hujan mencapai hampir 100\% di beberapa bagian Papua saat MJO kuat Fase 5 DJF. Di sebagian besar Sulawesi saat MJO kuat Fase 4 bulan JJA peningkatan curah hujan mencapai dua kali lipat. Wilayah dengan curah hujan lebih tinggi saat MJO lemah, diantaranya kawasan barat Indonesia (Sumatera dan Jawa) saat MJO Fase 3 di bulan JJA. Hujan ekstrem terjadi baik saat MJO kuat maupun MJO lemah. Frekuensi kejadian hujan ekstrem lebih tinggi saat MJO kuat di Sumatera bagian utara, Jawa bagian timur, Kalimantan bagian selatan, dan beberapa bagian di Pulau Papua saat Fase 3 di bulan DJF, dan pada wilayah Sulawesi dan Maluku saat Fase 4 di bulan JJA. Frekuensi curah hujan ekstrem lebih tinggi saat MJO lemah seperti pada wilayah Papua pada Fase 3 dan 4 bulan JJA.
\end{abstract}

Kata Kunci: MJO, Variasi Curah Hujan, Hujan Ekstrem, RMM, Persentil

\begin{abstract}
MJO propagation triggers increasing convective activity and influences the probability of rainfall events. Rain intensity and extreme rainfall events during MJO on DJF and JJA were analyzed over Indonesia. We conducted a composite analysis of rainfall data (CHIRPS) based on categorizing of the Real-time Multivariate MJO index for 11 years (2008-2018) based on its phase $(3,4,5)$ and amplitude (strong and weak). The extreme rainfall threshold was calculated using a 95\% percentile to determine the extreme rainfall events. The result shows that strong MJO events are more frequent than weak MJO events during DJF. During JJA, the frequencies of both MJO conditions are not significantly different. Rainfall over the western part of Indonesia increases during strong MJO phases 3 and 4 in DJF. Over the eastern part of Indonesia in DJF, rainfall increases reaching $100 \%$ during strong MJO phase 5 over several parts of Papua. In Sulawesi, strong MJO phase 4 in JJA contributes to double the precipitation. Rainfall during the weak MJO is higher over Sumatera and Java when MJO phase 3 (JJA). Moreover, extreme rainfall frequency can be higher not only when strong MJO but also when weak MJO. The higher extreme events frequency during strong MJO can be found in the northern part of Sumatera, the eastern part of Java, the southern part of Borneo, several parts in Papua during phase 3 MJO in DJF, and Sulawesi during phase 4, JJA. Higher extreme rainfall frequency during weak MJO can be found over Papua during MJO phases 3 and 4 in JJA.
\end{abstract}

Keywords: MJO, Rainfall Variability, Extreme Rainfall, RMM, Percentile 


\section{PENDAHULUAN}

Benua Maritim Indonesia (BMI) memiliki dinamika atmosfer kompleks yang menyebabkan tingginya variabilitas curah hujan. Variasi curah hujan di Indonesia dipengaruhi oleh fenomena skala global, regional, dan lokal, dalam skala waktu yang beragam seperti monsun Asia dan Australia (As-Syakur et al., 2016), El Nino Southern Oscillation (ENSO; Lestari et al., 2016; Supari et al., 2017), dan Madden Julian Oscillation (Peatman et al., 2014; Hidayat et al., 2016). Di antara berbagai fenomena tersebut, terdapat fenomena intra-seasonal yang berpengaruh besar terhadap variabilitas curah hujan di Indonesia yaitu Madden Julian Oscillation (MJO) yang dikenal sebagai sebuah sel osilasi angin zonal di ketinggian $850 \mathrm{mb}$ dan $150 \mathrm{mb}$ dengan periode 41-53 hari (Madden \& Julian, 1971). MJO dideteksi terjadi di sepanjang ekuator dan berpropagasi dari barat menuju timur (Zhang, 2005; Madden \& Julian, 1972).

Wilayah penjalaran dan amplitudo MJO (menyatakan tingkat aktivitas/kuat-lemahnya MJO) definisikan secara sederhana melalui indeks-indeks yang telah dikembangkan oleh beberapa lembaga/instansi. Climate Prediction Center dari National Service Weather, National Oceanic and Atmospheric Administration (CPC, NWS-NOAA) menyusun indeks MJO pada masing-masing fase dengan orde 5 harian. Sehingga analisis keterkaitan curah hujan dan MJO menggunakan indeks ini perlu penyesuaian data curah hujan menjadi data pentad atau data dengan periode waktu lima harian. Selain itu, The Bureau of Meteorology Austraila (BoM) juga melakukan pemantauan MJO dengan menyediakan informasi mengenai waktu, lokasi, dan besaran kekuatan MJO. Dalam hal ini, penentuan MJO menggunakan All Season Realtime Multivariate MJO (RMM) Index yang diturunkan menggunakan metode Empirical Orthogonal Functions (EOFs) dari parameter angin pada ketinggian $850 \mathrm{hPa}$ dan $200 \mathrm{hPa}$ dan Outgoing Longwave Radiation (OLR) (Wheeler \& Hendon, 2004). RMM tersedia dalam data harian, sehingga memungkinkan untuk secara langsung dibandingkan dengan data harian curah hujan baik observasi maupun satelit.

Propagasi MJO dapat dilihat dari anomali OLR yang berkaitan dengan pergerakan aktivitas konveksi ke arah timur. Anomali negatif (positif) menunjukkan peningkatan (penurunan) aktivitas konveksi (Hidayat \& Kizu., 2010). Aktivitas konveksi ini dihubungkan dengan kejadian curah hujan di Indonesia. Secara umum, peningkatan curah hujan di Indonesia terjadi pada saat fase aktif MJO.

Hidayat \& Kizu (2010) mengemukakan bahwa 26 dari 31 titik stasiun yang tersebar di Jawa, Sumatera, Kalimantan, Sulawesi dan Nusa Tenggara mempunyai nilai anomali curah hujan positif pada saat fase aktif MJO. Pada fase MJO aktif ini, variasi curah hujan lebih dominan terjadi di lautan daripada daratan (Hidayat et al., 2016; Rauniyar \& Walsh, 2011). Hasil simulasi model menunjukkan bahwa aktivitas MJO di lautan meningkat melalui peningkatan penguapan akibat anomali suhu permukaan laut (SPL) positif sebelum terjadinya konveksi MJO (Wheeler \& Hendon, 2004). Di sisi lain, pengaruh MJO di daratan masih belum diketahui dengan jelas, terutama di kawasan BMI. Salah satu penyebabnya diduga karena curah hujan pada wilayah tertentu lebih kuat dipengaruhi oleh faktor lokal seperti di Pontianak (Yoneyama, 2015) dan Sumatera (Hidayat \& Kizu, 2010).

Kajian mengenai hubungan MJO dengan curah hujan di Indonesia sudah dilakukan pada penelitian-penelitian sebelumnya dengan beberapa area yang spesifik, baik menggunakan data in-situ, satelit, maupun melalui simulasi model (Chang et al., 2005; Hidayat \& Kizu, 2010; Kamimera et al., 2012; Wu et al., 2013; dan Peatman et al., 2014). Akan tetapi, penelitian terkait curah hujan ekstrem dan MJO untuk kajian wilayah Indonesia secara menyeluruh masih terbatas. Wicaksono et al. (2016) menunjukkan bahwa curah hujan ekstrem di Katulampa, Jawa Barat dikaitkan oleh adanya mekanisme transpor uap air yang memicu aktivitas konveksi di Pulau Jawa saat MJO aktif. Begitupun Wu et al. (2013) yang menyatakan bahwa fase aktif MJO juga berperan besar terhadap pembentukan curah hujan ekstrem di Pulau Jawa bagian barat saat terjadi banjir Januari 2013.

Wilayah-wilayah di Indonesia yang memiliki karakteristik beragam akan memiliki respon curah hujan yang berbeda terhadap penjalaran MJO. Selain fase aktif MJO, Hidayat et al. (2016) menyatakan bahwa amplitudo MJO pada fase aktif pun berperan penting terhadap variasi curah hujan dan curah hujan ekstrem di Indonesia. Sehingga menarik untuk dikaji mengenai kondisi curah hujan dan curah hujan ekstrem di seluruh Indonesia pada saat MJO melintas dan pengaruh nilai amplitudonya. Oleh karena itu, penelitian ini akan menganalisis kondisi curah hujan dan curah hujan ekstrem di Indonesia saat MJO kuat dan lemah (Fase 3, 4 dan 5). Pemilihan fase didasarkan pada wilayah penjalaran MJO di sekitar BMI yaitu, meliputi Fase 3 (Samudera Hindia-wilayah barat Indonesia), 4 (benua maritim) dan 5 (benua maritim). Analisis dilakukan pada saat terjadinya Monsun Asia (Desember-Januari-Februari, DJF) dan Monsun Australia (Juni-Juli-Agustus, JJA). Kajian ini bertujuan untuk memahami kondisi curah hujan dan curah hujan ekstrem pada saat MJO kuat dan lemah di suatu wilayah di Indonesia baik intensitasnya maupun frekuensi kejadiannya dengan membandingkan kondisi temporal dan spasial saat DJF dan JJA. 


\section{METODE}

Pada penelitian ini digunakan data Realtime Multivariate MJO (RMM) Index yaitu indeks MJO yang dikembangkan oleh Bureau of Meteorology (BoM) untuk mengidentifikasi tanggal dan jumlah kejadian MJO (Wheeler \& Hendon, 2004). Adapun fase MJO difokuskan pada Fase 3, 4, dan 5, dimana penjalaran MJO berada di sekitar BMI. Setiap fase ini dibagi menjadi dua kategori yaitu MJO kuat dan MJO lemah yang diidentifikasi berdasarkan nilai amplitudonya. MJO lemah diindikasikan dengan nilai amplitudo RMM kurang dari satu, sedangkan MJO kuat ditandai dengan nilai amplitudo lebih dari sama dengan satu. Selain itu, untuk menganalisis kondisi curah hujan dan curah hujan ekstrem saat MJO kuat dan lemah Fase 3, 4, dan 5, penelitian ini memanfaatkan data curah hujan harian Climate Hazards Group Infrared Precipitation with Stations (CHIRPS) versi 2.0 dengan resolusi $0,05^{\circ}$ sepanjang tahun 2008 2018 (Funk et al., 2015). Adapun untuk identifikasi awal aktivitas konveksi saat MJO aktif pada fase tersebut digunakan data Outgoing Longwave Radiation (OLR) NCEP DOE Reanalysis II yang diperoleh melalui https://www.esrl.noaa.gov/psd/data/gridded/data. ncep.reanalysis2.html.

Analsis kondisi curah hujan dilakukan pada dua periode berbeda yaitu bulan DesemberJanuari-Februari (DJF) dan Juni-Juli-Agustus (JJA). Analisis dimulai dengan melihat kondisi rerata curah hujan pada dua periode tersebut, sepanjang tahun 2008-2018. Kemudian untuk mengetahui penjalaran fase MJO aktif pada periode tersebut dilakukan analisis komposit rerata OLR pada tanggal-tanggal kejadian MJO Fase 3, 4 dan 5. Adapun kondisi curah hujan di Indonesia saat MJO kuat dan lemah, dianalisis melalui komposit curah hujan pada tanggal kejadian MJO kuat dan MJO lemah Fase 3, 4, dan 5. Curah hujan komposit tiap-tiap fase dibandingkan antara MJO kuat dan MJO lemah dengan menghitung presentase anomalinya (Gambar 1). Frekuensi kejadian MJO kuat dan MJO lemah pada setiap periode juga dibandingkan untuk memperoleh gambaran intensitas MJO di wilayah kajian.

Komposit curah hujan harian saat MJO lemah dan MJO kuat, fase 3, 4 dan 5, pada DJF dan JJA

Presentase anomali curah hujan dihitung dengan perhitungan berikut:

(((MJO kuat - MJO lemah)/MJO lemah) $\left.{ }^{\star} 100 \%\right)$

Gambar 1. Perhitungan presentase anomali curah hujan.
Analisis kondisi curah hujan ekstrem dilakukan dengan menghitung persentase frekuensi curah hujan di atas ambang batas curah hujan ekstrem menggunakan parameter statistik data setiap grid, yaitu nilai presentil $95 \%$. Pemilihan presentil ini didasarkan pada pemahaman bahwa sebaran data curah hujan berbeda-beda di setiap wilayah, sehingga memiliki besaran curah hujan ekstrem yang berbeda-beda pula. Ambang batas curah hujan ekstrem ditentukan menggunakan presentil 95\% dari data curah hujan periode DJF dan JJA selama 2008-2018. Untuk melihat frekuensi terjadinya curah hujan ekstrem, dihitung jumlah kejadian curah hujan ekstrem di setiap grid pada saat MJO kuat dan lemah Fase 3, 4, dan 5. Kemudian dipersentasekan berdasarkan jumlah tanggal kejadian pada masing-masing fase dan periode. Selanjutnya untuk mengetahui perbandingan persentase curah hujan ekstrem saat MJO kuat dengan saat MJO lemah, maka dihitung anomali persentase frekuensinya seperti pada Gambar 2

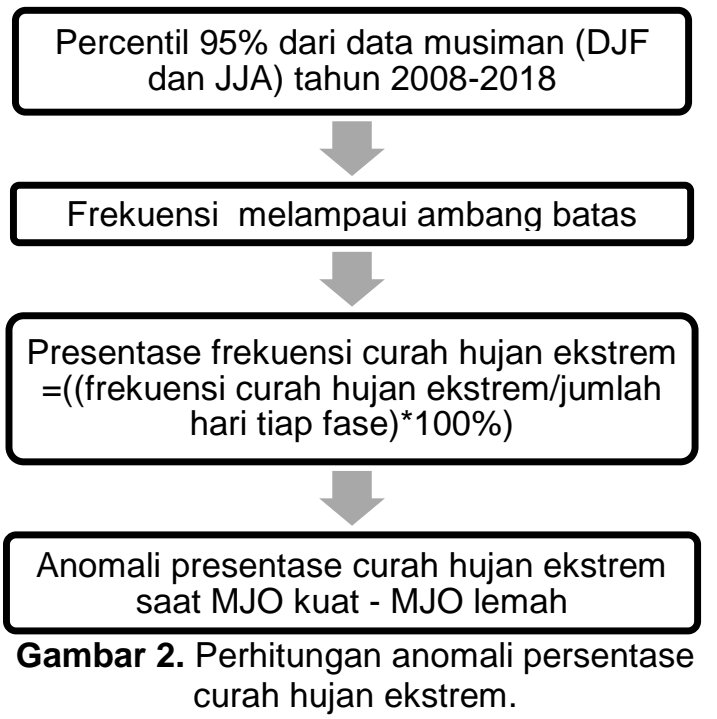

\section{HASIL DAN PEMBAHASAN}

\subsection{Rerata Curah Hujan bulan DJF dan JJA}

Berdasarkan rerata curah hujan harian pada bulan DJF sepanjang tahun 2008-2018, curah hujan dengan intensitas $>10 \mathrm{~mm} /$ hari terjadi di Pulau Jawa, Nusa Tenggara, bagian barat dan selatan Pulau Sumatera, bagian tengah Pulau Kalimantan, bagian selatan Pulau Sulawesi, dan bagian selatan Pulau Papua (Gambar 3a). Sedangkan wilayah lainnya di Indonesia menunjukkan curah hujan $<10$ $\mathrm{mm} /$ hari. Pulau Jawa memiliki curah hujan merata di seluruh wilayah dengan curah hujan tertinggi di Jawa bagian tengah yang mencapai 20-30 mm/hari. Curah hujan tinggi juga terjadi di Sulawesi Selatan yang mencapai 20-25 $\mathrm{mm} /$ hari. Kedua wilayah ini dipengaruhi oleh 
Monsun Asia-Australia dimana pada bulan November-April merupakan monsun Asia yang menyebabkan terjadinya musim hujan (Lee, 2015; Aldrian \& Susanto, 2003). Sebaliknya, Pulau Sulawesi bagian utara dan Maluku memiliki curah hujan paling rendah yaitu $<5$ $\mathrm{mm} /$ hari.
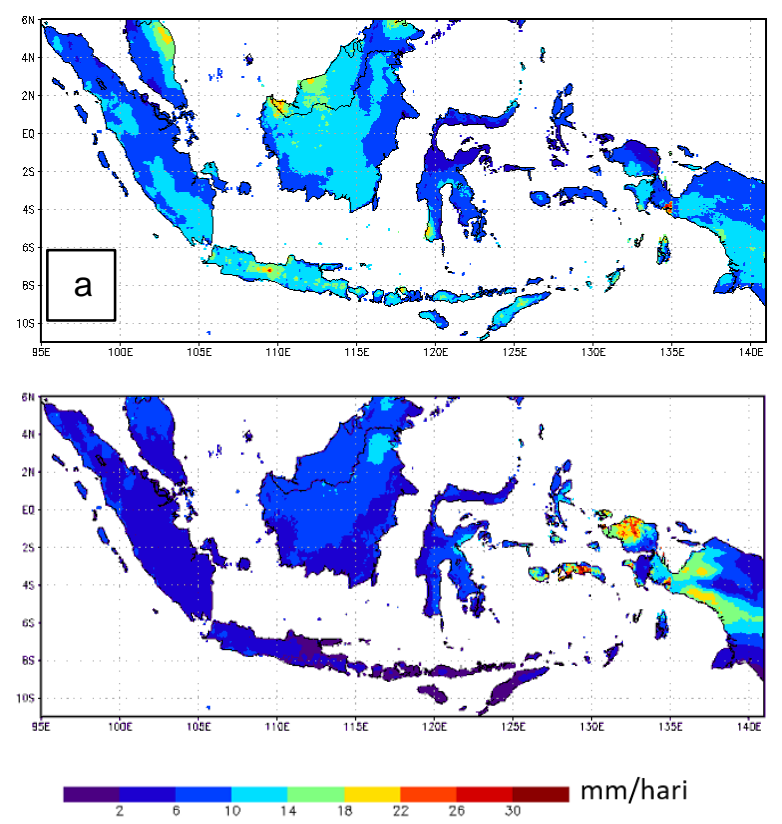

Gambar 3. Curah Hujan rerata harian selama tahun 2008-2018, (a) pada bulan DJF dan (b) JJA.

Monsun Asia-Australia mempunyai pengaruh cukup dominan terhadap curah hujan di wilayah bagian tengah dan barat BMI (Lee, 2015). Monsun Australia terjadi pada bulan MeiOktober dimana beberapa wilayah di Indonesia mengalami musim kemarau (Aldrian \& Susanto, 2003). Seperti terlihat pada Gambar 3b, hampir seluruh bagian di Pulau Jawa, Nusa Tenggara dan Sumatera memiliki rerata curah hujan harian yang rendah pada bulan JJA sekitar 2-6 $\mathrm{mm} /$ hari, bahkan di Sumba dan Nusa Tenggara Timur curah hujan hanya $<2 \mathrm{~mm} /$ hari. Fenomena menarik ditemukan di Pulau Maluku dan bagian utara Papua Barat yang menunjukkan rerata curah hujan harian tinggi yaitu berkisar antara 20-30 mm/hari. Chang et al. (2005) menyatakan bahwa hal ini terjadi karena adanya pola pergerakan angin monsun dingin Australia dari Pasifik barat daya dan Laut Arafuru. Pola di kedua wilayah tersebut berkebalikan dengan pola monsunal yang puncak curah hujannya terjadi pada bulan JJA atau disebut pola lokal/anti-monsunal (Aldrian \& Susanto, 2003).

\subsection{Komposit OLR saat MJO Aktif bulan DJF dan JJA}

Selain pola umum musiman curah hujan seperti pada Gambar 3, curah hujan di Indonesia juga dominan dipengaruhi oleh fenomena intra-seasonal yaitu MJO (Zhang, 2005; Kiladis et al., 2009). MJO melintasi wilayah BMI pada Fase 3, 4, dan 5. Pada saat fase MJO aktif dapat terjadi peningkatan aktivitas konveksi di beberapa wilayah Indonesia yang dilewatinya. Parameter OLR dapat merepresentasikan aktivitas konveksi, sehingga dapat melihat penjalaran MJO di wilayah Indonesia.

Gambar 4 menunjukan adanya pola anomali OLR yang berbeda pada bulan DJF dan JJA di setiap fase MJO. Pada bulan DJF, anomali OLR negatif pada Fase 3 terjadi di bagian barat wilayah Indonesia yaitu Sumatera hingga Pulau Jawa dengan nilai berkisar -25 sampai $-5 \mathrm{~W} \cdot \mathrm{m}^{-2}$, sedangkan anomali positif terjadi di bagian selatan Pulau Papua dan Nusa Tenggara (Gambar 4a). Anomali OLR negatif (positif) merepresentasikan adanya peningkatan (pengurangan) aktivitas konveksi di wilayah tersebut (Hidayat \& Kizu, 2010). Pada Fase 3 MJO aktif ini terjadi peningkatan aktivitas konveksi di Pulau Sumatera yang ditandai dengan adanya anomali OLR negatif. Anomali OLR negatif ini bergerak lebih luas menuju timur walaupun dengan nilai anomali yang lebih kecil yaitu hanya berkisar antara -20 hingga $-5 \mathrm{~W} . \mathrm{m}^{-2}$ (Gambar 4b). Kemudian anomali negatif bergerak semakin ke timur dan selatan pada Fase 5 dengan nilai anomali tertinggi berada di bagian selatan Nusa Tenggara (Gambar 4c). Kondisi ini sejalan dengan kajian $\mathrm{Kim}$ et al. (2017) yang menyatakan bahwa MJO sangat jelas terjadi pada musim dingin Asia dan anomali konveksi yang dikaitkan dengan MJO terpusat di Belahan Bumi Selatan.

Pada saat MJO aktif Fase 3 bulan JJA, anomali OLR negatif berada di bagian utara Indonesia mencakup sebagian Pulau Sumatera, Kalimantan, bagian tengah dan utara Pulau Sulawesi. Kemudian bergerak ke arah timur pada Fase 4 menuju Kepulauan Maluku dan Papua Barat. Pada Fase 4 juga muncul anomali OLR positif di bagian barat dan selatan Pulau Sumatera. Adapun pada Fase 5, anomali negatif OLR bergerak semakin ke timur menuju bagian utara Pulau Papua, sedangkan anomali OLR positif bergerak menuju Pulau Kalimantan dan Jawa. Secara umum, anomali OLR negatif pada bulan JJA baik pada Fase 3, 4, maupun 5 terjadi di bagian utara Indonesia. Berdasarkan penelitian sebelumnya, Zhang \& Dong (2004) menyatakan saat musim panas Asia, sinyal konvektif utama MJO berada di belahan bumi utara, dan propagasi MJO ke arah timur sering menyertai komponen propagasi ke arah utara di atas Samudera Pasifik (Kim et al., 2017), serta menunjukkan propagasi ke arah timur sepanjang benua maritim yang lebih lemah (Wu \& Hsu, 2009).

Perbedaan pola anomali negatif OLR pada saat MJO aktif Fase 3, 4, dan 5 bulan DJF dan JJA menunjukkan adanya perbedaan aktivitas konveksi di setiap wilayah di Indonesia pada fase-fase tersebut yang dapat 
berkontribusi pula terhadap variasi curah hujan di wilayah tersebut. Hidayat et al. (2016) menyatakan bahwa tidak hanya fase MJO yang berperan dalam variabilitas curah hujan di Indonesia, tetapi juga amplitudo (kuat dan lemah) MJO. Sehingga, kondisi curah hujan dan curah hujan ekstrem pada saat MJO aktif (kuat dan lemah) Fase 3, 4 dan 5 akan diidentifikasi melalui analisis komposit curah hujan pada bagian selanjutnya.

\subsection{Frekuensi MJO Kuat dan Lemah pada bulan DJF dan JJA}

Frekuensi kejadian MJO dianalisis untuk membandingkan jumlah kejadian MJO kuat dan lemah pada periode musim DJF dan JJA. Jumlah hari MJO kuat dan lemah ditunjukkan pada Gambar 5. Berdasarkan indeks RMM, terdapat 361 kejadian MJO kuat dan lemah pada Fase 3, 4, dan 5 saat bulan DJF dan 271 saat JJA selama periode tahun 2008-2018. Pada bulan DJF, jumlah hari MJO kuat dan lemah bervariasi antara 29-110 kejadian. Pada

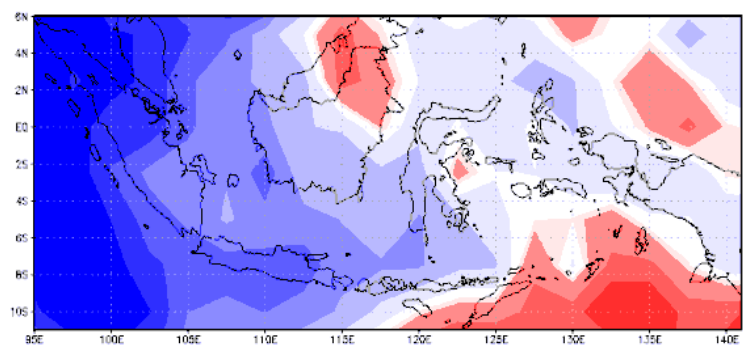

(a)

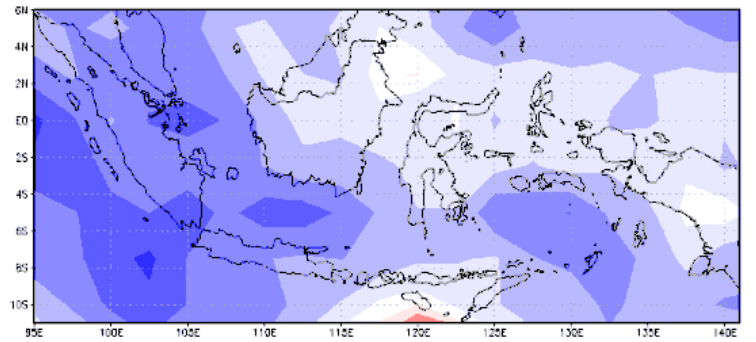

(c)

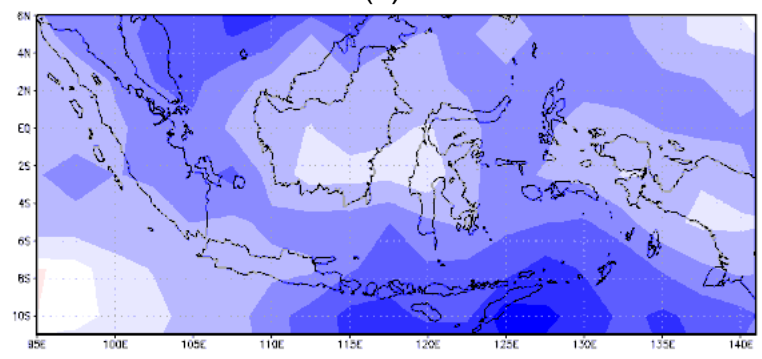

(e) periode musim ini, MJO kuat saat Fase 3, 4, dan 5 lebih sering terjadi dibanding kejadian MJO lemah, dengan perbedaan yang hampir mencapai $50 \%$.

Jumlah hari MJO kuat dan lemah pada bulan JJA berkisar antara 40-48 kejadian. Pada periode ini tidak terdapat perbedaan signifikan antara jumlah hari saat MJO kuat dan lemah. Frekuensi kejadian MJO kuat dan lemah pada bulan JJA lebih rendah dibandingkan bulan DJF.

\subsection{Presentase Anomali Curah Hujan}

Presentase perubahan nilai curah hujan saat MJO kuat dibandingkan MJO lemah pada Fase 3, 4, dan 5 dapat digunakan untuk melihat kenaikan/penurunan curah hujan di suatu wilayah seperti pada Gambar 6. Nilai persentase positif (negatif) menunjukkan curah hujan saat MJO kuat lebih tinggi (lebih rendah) dibanding saat MJO lemah. Adapun nilai persentase mendekati nol menunjukkan perbedaan yang tidak signifikan antara curah hujan saat MJO kuat dan MJO lemah.

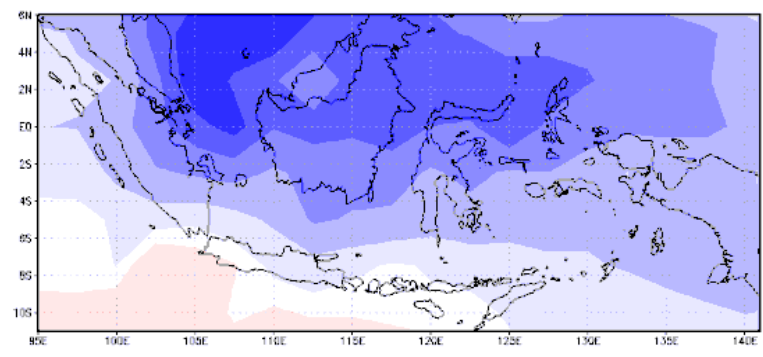

(b)

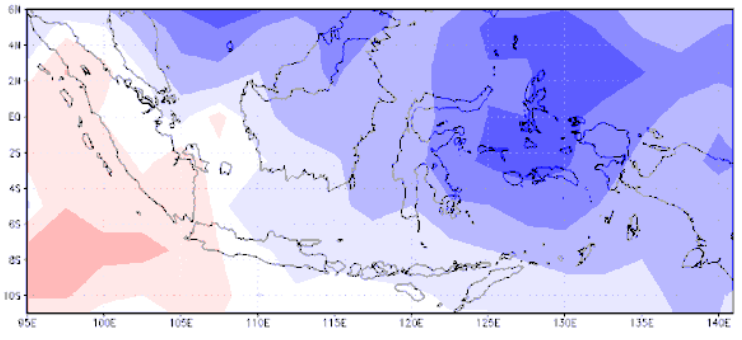

(d)

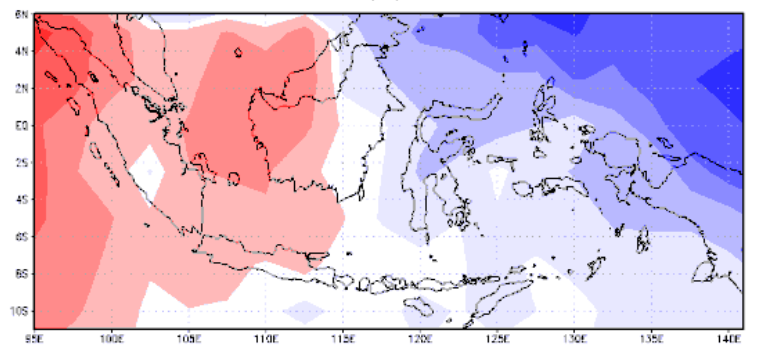

(f)

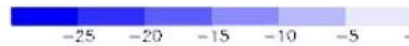

W. $\mathrm{m}^{-2}$

Gambar 4. Anomali Outgoing Longwave Radiation (OLR) pada saat MJO aktif bulan DJF, Fase 3 (a), Fase 4 (b), Fase 5 (c) dan bulan JJA Fase 3 (d), Fase 4 (e) dan Fase 5 (f), selama tahun 2008-2018. 


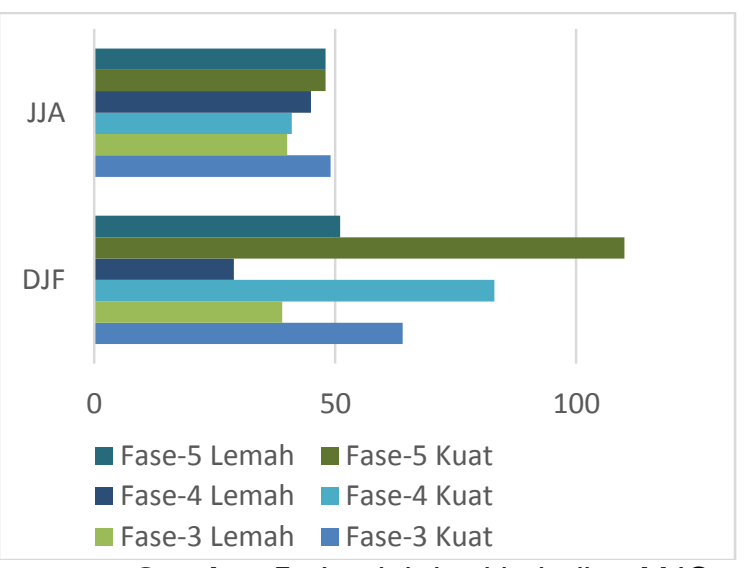

Gambar 5. Jumlah hari kejadian MJO kuat/lemah saat Fase 3, 4, dan 5 pada DJF dan JJA.

Gambar 6 menunjukkan bahwa respon curah hujan di sebagian wilayah Indonesia saat MJO kuat tidak selalu positif (menunjukkan curah hujan yang lebih tinggi) dibanding saat MJO lemah baik pada bulan DJF maupun JJA. Selain itu terdapat wilayah yang memiliki besaran curah hujan yang sama saat terjadi MJO kuat maupun MJO lemah.

Pada bulan DJF, respon positif
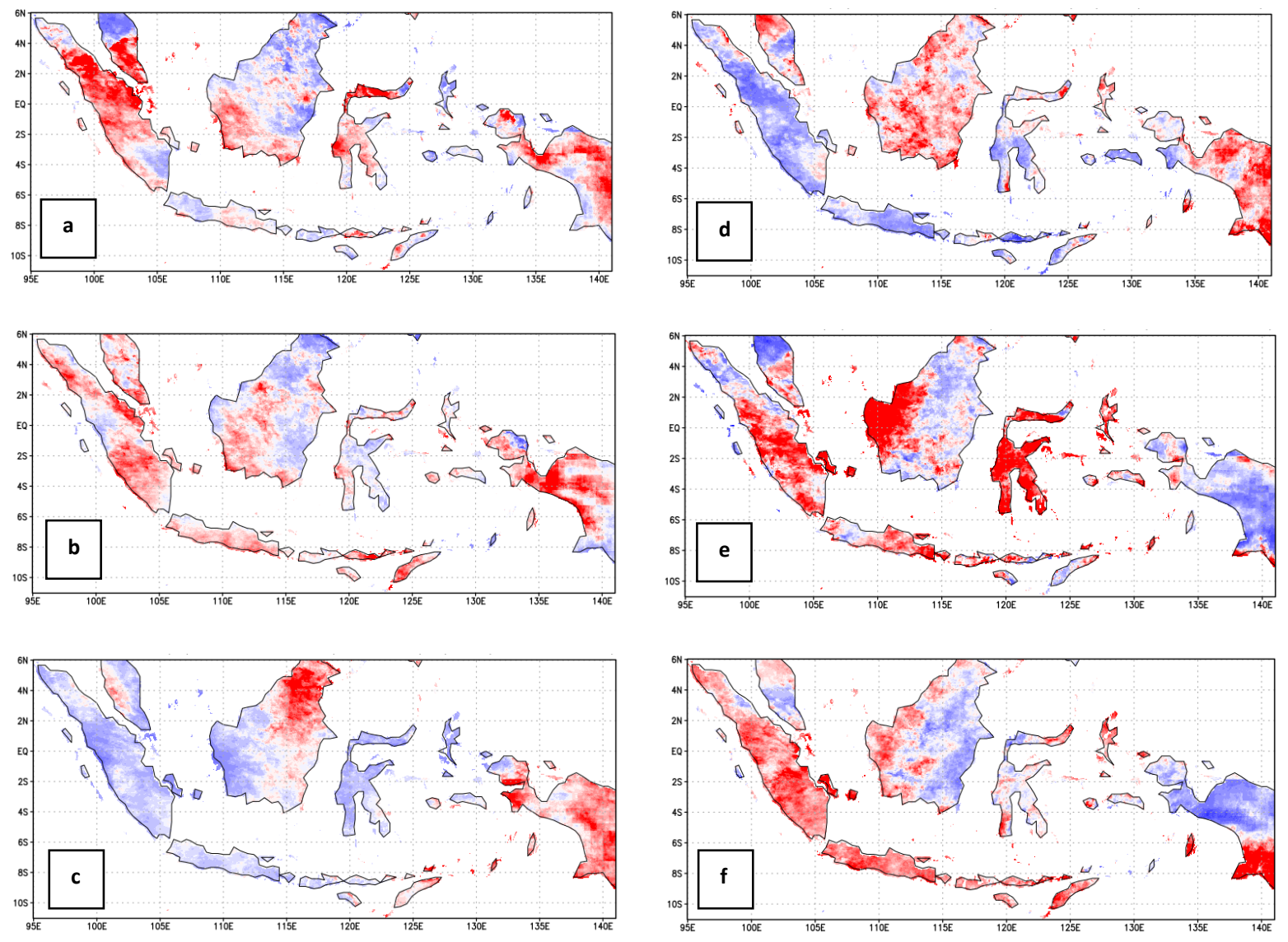

$-100-90-80-70-60-50-40-30-20-10 \quad 0 \quad 10 \quad 20 \quad 30 \quad 40 \quad 50 \quad 60 \quad 70 \quad 80 \quad 90 \quad 100$

Gambar 6. Persentase perubahan curah hujan saat MJO kuat dibanding saat MJO lemah pada bulan DJF di (a) Fase 3, (b) Fase 4, (c) Fase 5 dan bulan JJA di (d) Fase 3, (e) Fase 4, (f) Fase 5 tahun 2008-2018. 
lain (warna biru). Hal ini dikarenakan wilayah wilayah timur BMI, sehingga pengaruh MJO pada wilayah barat BMI tidak signifikan. Penjalaran MJO tersebut ditunjukkan pada Gambar 4, aktivitas konveksi bergerak menuju ke Indonesia bagian timur. Hasil ini sejalan dengan kajian oleh Oh et al. (2011) yang menemukan bahwa pengaruh MJO Fase 5 menurun di beberapa wilayah seperti Sumatera, Jawa, dan Kalimantan.

Pada bulan DJF juga ditemukan bahwa di sebagian besar Papua, curah hujan saat MJO kuat mencapai dua kali curah hujan saat MJO lemah baik pada Fase 3, 4, maupun 5 (Gambar 6 a-c). Sebaran wilayah dengan curah hujan yang lebih tinggi tersebut meluas di Papua pada saat MJO Fase 5, dibanding Fase 3 dan 4.

Secara umum, pada bulan JJA, wilayah selatan BMI memiliki curah hujan yang lebih tinggi pada saat MJO kuat dibanding saat MJO lemah terutama pada Fase 4 dan 5 (Gambar $6 e$ dan f). Hal ini berbeda pada Fase 3, ditemukan pola yang unik, khususnya pada kawasan barat dan selatan Indonesia (Sumatera dan Jawa). Pada saat MJO Fase 3, Sumatera dan Jawa memiliki nilai curah hujan lebih rendah saat MJO kuat (ditunjukkan oleh warna biru Gambar 6d). Pada periode dan fase yang sama, Kalimantan memiliki curah hujan yang lebih tinggi saat MJO kuat dengan sebaran wilayah yang hampir merata pada Fase 3, dan di wilayah barat pada Fase 4 dan 5 . Pengaruh MJO di wilayah Kalimantan sulit untuk disimpulkan, diduga karena wilayah ini memiliki faktor lokal yang dominan, khususnya di wilayah Pontianak dan Pulau Kalimantan bagian barat daya (Yoneyama \& Hayati, 2015).

Pada wilayah Sulawesi, MJO kuat Fase 4 bulan JJA merupakan kondisi yang memperlihatkan kenaikan curah hujan paling signifikan dengan presentase perubahan curah hujan saat MJO kuat dibandingkan MJO lemah yang mencapai 100\% (Gambar 6e). Kondisi serupa juga terjadi di Sumatera bagian tengah dan Kalimantan yang berbatasan dengan Laut Cina Selatan. Kondisi ini menunjukkan bahwa di wilayah-wilayah tersebut pada bulan JJA, MJO kuat Fase 4 memiliki curah hujan dua kali lipat lebih tinggi dibanding saat kondisi MJO lemah.

\subsection{Anomali Presentase Frekuensi Curah Hujan Ekstrem}

Berdasarkan nilai ambang batas persentil 95\% diperoleh besaran curah hujan ekstrem yang berbeda di setiap wilayah. Frekuensi terjadinya curah hujan ekstrem di Indonesia cukup bervariasi termasuk pada saat fase aktif MJO (Fase 3, 4, dan 5), baik MJO kuat maupun lemah. Gambar 7 menunjukkan anomali persentase frekuensi curah hujan penjalaran MJO Fase 5 berada di ekstrem yaitu jumlah kejadian curah hujan ekstrem saat MJO kuat dibanding saat MJO lemah. Warna merah (biru) menunjukkan persentase kejadian curah hujan ekstrem yang lebih banyak (sedikit) pada MJO kuat dibandingkan dengan saat MJO lemah. Secara umum, terdapat wilayah yang memiliki curah hujan ekstrem lebih sering saat MJO kuat (wilayah dengan warna merah), namun terdapat pula yang memiliki lebih banyak curah hujan ekstrem saat MJO lemah (warna biru). Pada Fase 3 dan 4 bulan DJF dan JJA, perbedaan frekuensi curah hujan ekstrem saat MJO kuat dan lemah lebih bervariasi dibandingkan pada Fase 5 bulan DJF dan JJA (Gambar 7 a, b, d dan e).

Pada bulan JJA terdapat beberapa wilayah yang menarik untuk dikaji lebih lanjut. Gambar 7d menunjukkan bahwa Pulau Sulawesi memiliki frekuensi kejadian curah hujan ekstrem yang lebih tinggi saat MJO kuat dibanding saat MJO lemah Fase 4. Pada saat MJO Fase 4, presentase frekuensi kejadian curah hujan ekstrem saat MJO kuat, 15\% lebih tinggi dibanding saat MJO lemah di Sulawesi bagian Tengah, Barat, dan Selatan. Sedangkan di wilayah Gorontalo dan Sulawesi Utara, presentase kejadian curah hujan sktrem mencapai $10 \%$ lebih banyak terjadi saat MJO kuat. Hal ini sejalan dengan hasil pada Gambar 6e yang menunjukkan bahwa Pulau Sulawesi memiliki nilai curah hujan paling tinggi pada MJO kuat Fase 4 bulan JJA yaitu intensitas curah hujan saat MJO kuat dua kali lipat MJO lemah. Begitupun dengan Pulau Maluku yang memiliki respon hampir sama dengan Sulawesi. Sehingga dapat disimpulkan bahwa MJO kuat pada Fase 4 di bulan JJA memengaruhi kenaikan intensitas curah hujan dan frekuensi curah hujan ekstrem di Pulau Sulawesi dan Maluku

Kejadian curah hujan ekstrem yang terjadi di Pulau Sumatera dan Jawa lebih banyak terjadi saat MJO Fase 3 dan 4 pada bulan DJF dan JJA. Pada bagian utara Pulau Sumatera, curah hujan ekstrem lebih sering terjadi saat MJO kuat pada bulan DJF Fase 3 (Gambar 7a), sedangkan pada bulan JJA terjadi kondisi yang berkebalikan (Gambar 7d). Respon berkebalikan antara DJF dan JJA juga terlihat di wilayah Jawa bagian barat dan timur. Frekuensi kejadian curah hujan ekstrem lebih sering terjadi saat MJO lemah pada bulan DJF di wilayah barat Pulau Jawa (Gambar 7a), sedangkan saat JJA frekuensi kejadian curah hujan ekstrem lebih sering terjadi saat MJO kuat (Gambar 7d). Adapun Pulau Jawa bagian timur memiliki kondisi yang berkebalikan dengan Jawa bagian barat, pada periode dan fase yang sama.

Di wilayah Kalimantan, kejadian curah hujan ekstrem paling banyak terjadi ketika MJO 

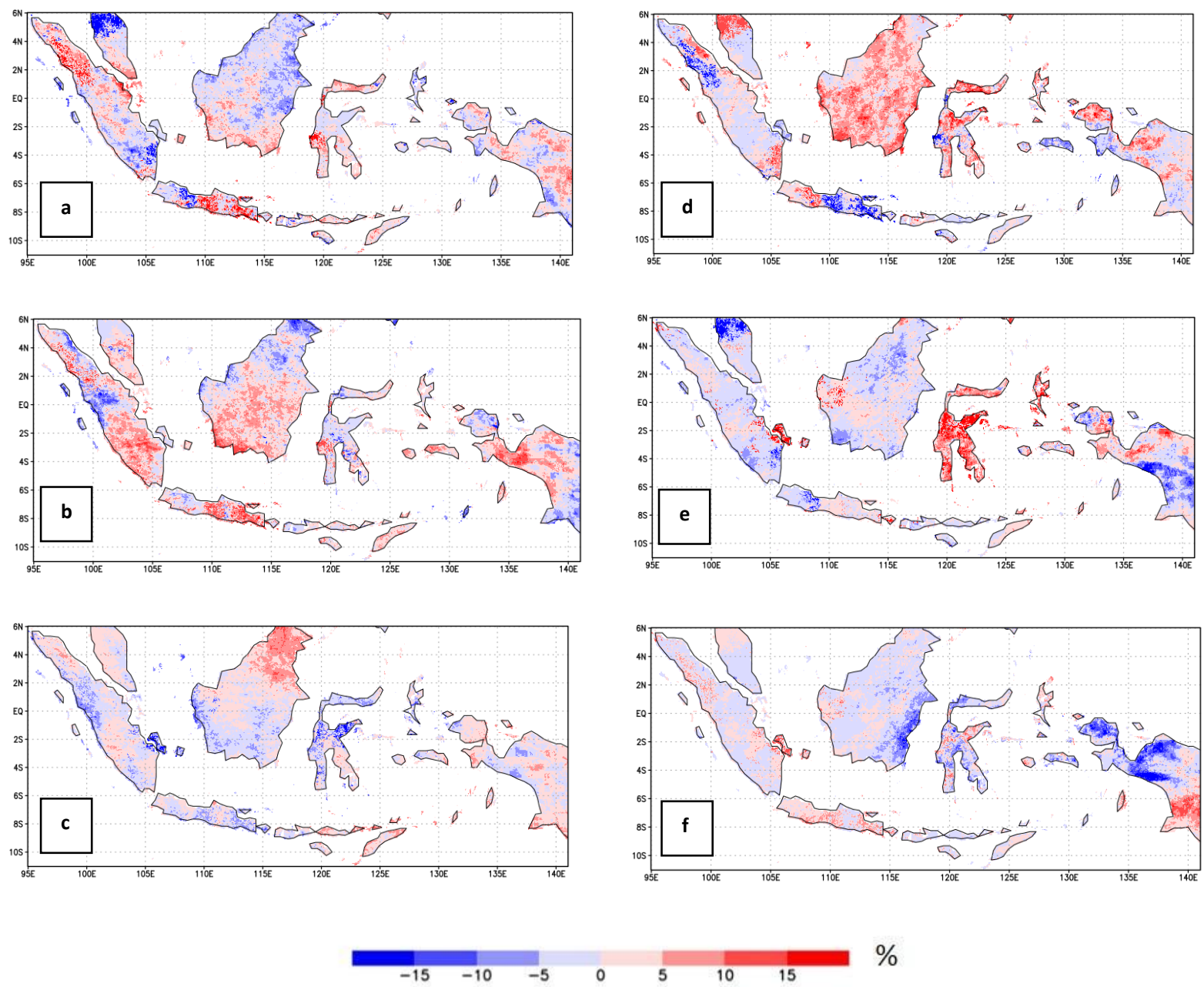

Gambar 7. Anomali presentase frekuensi curah hujan ekstrem saat MJO kuat dibanding MJO lemah bulan DJF di (a) Fase 3, (b) Fase 4, (c) Fase 5 dan bulan JJA di (d) Fase 3, (e) Fase 4, dan (f) Fase 5 tahun 2008-2018.

kuat Fase 3 bulan JJA, diikuti dengan Fase 4 dan 3 bulan DJF. Sedangkan pada wilayah Papua kejadian curah hujan ekstrem bulan JJA lebih tinggi pada saat Fase 3 (warna merah, Gambar 7d). Kondisi yang menarik terlihat di wilayah Papua pada Fase 3 dan 4 bulan JJA yang menunjukkan kondisi ekstrem lebih sering terjadi saat MJO lemah (warna biru di Pulau Papua pada Gambar 7e dan 7f).

\section{KESIMPULAN}

Anomali OLR dapat merepresentasikan pergerakan MJO aktif yang berkaitan dengan aktivitas konveksi. Anomali OLR negatif pada bulan DJF terjadi di bagian barat Indonesia saat MJO aktif Fase 3 dan bergerak ke arah timur dan selatan saat Fase 4 dan 5. Sedangkan pada saat Fase 3 bulan JJA, anomali negatif OLR berada di bagian utara Indonesia meliputi sebagian wilayah Sumatera, Kalimantan, dan Pulau Sulawesi bagian tengah dan Utara. Pada MJO aktif Fase 4 dan 5, anomali OLR negatif bergerak semakin ke timur.
Analisis kondisi curah hujan saat MJO kuat dan lemah menunjukkan respon yang berbeda di setiap wilayah baik berdasarkan fase maupun periode waktunya. MJO kuat lebih sering terjadi saat DJF dengan frekuensi $50 \%$ lebih banyak dibanding MJO lemah. Saat JJA, frekuensi MJO kuat dan lemah tidak berbeda secara signifikan. Saat DJF, di wilayah Indonesia bagian barat terjadi peningkatan intensitas curah hujan saat MJO kuat Fase 3 dan 4, namun MJO kuat Fase 5 tidak memengaruhi kenaikan curah hujan pada wilayah ini. Selain itu, wilayah timur Indonesia memiliki peningkatan curah hujan hampir $100 \%$ saat MJO kuat Fase 5 pada bulan DJF. Begitu pula di Sulawesi saat MJO kuat Fase 4 di bulan JJA memiliki curah hujan dua kali lipat dibanding fase lemahnya. Sebaliknya respon berbeda ditunjukkan di kawasan barat Indonesia (Sumatera dan Jawa), curah hujan saat MJO kuat lebih kecil dibanding MJO lemah pada Fase 3 bulan JJA. Selain itu pada wilayah Sumatera bagian selatan dan Jawa bagian barat, curah hujan lebih tinggi saat MJO lemah juga terjadi pada Fase 5 bulan DJF. 
Berdasarkan diagram anomali presentase frekuensi curah hujan ekstrem, jumlah kejadian curah hujan ekstrem dapat lebih tinggi baik saat MJO kuat maupun MJO lemah. Saat MJO Fase 3 bulan DJF, kejadian curah hujan ekstrem lebih banyak terjadi saat MJO kuat dibanding MJO lemah di wilayah Sumatera bagian utara, Jawa bagian timur, Kalimantan bagian selatan, dan beberapa bagian di Pulau Papua. Selain itu, MJO kuat pada Fase 4 di bulan JJA memengaruhi kenaikan frekuensi curah hujan ekstrem di Pulau Sulawesi dan Maluku. Sebaliknya, kondisi ekstrem di wilayah Papua lebih sering terjadi saat MJO lemah pada Fase 3 dan 4 pada bulan JJA.

Hasil kajian ini dapat digunakan untuk memahami wilayah yang memiliki respon positif/negatif terhadap MJO kuat pada fase dan waktu tertentu. Selain itu, dapat diketahui pula bagaimana MJO kuat dan MJO lemah berkaitan dengan frekuensi curah hujan ekstrem di wilayah Indonesia. Studi lebih lanjut dapat dilakukan pada wilayah yang memiliki respon unik curah hujan dan curah hujan ekstrem terhadap MJO kuat dan MJO lemah pada bulan DJF dan JJA. Kajian dapat diperdalam dengan melibatkan faktor lain seperti topografi dan fenomena atmosfer lainnya (monsun, ENSO, dan lain-lain).

\section{Ucapan Terima Kasih}

Penulis mengucapkan terima kasih kepada Pusat Sains dan Teknologi Atmosfer, Lembaga Penerbangan dan Antariksa Nasional yang telah memberikan dukungan dalam proses penelitian dan penulisan ini.

\section{DAFTAR PUSTAKA}

Aldrian, E., Susanto, R.D. (2003). Identification of three dominant rainfall regions within Indonesia and their relationship to sea surface temperature. International Journal of Climatology, 23(12), 1435-1452. doi: 10.1002/joc.950

As-Syakur, A. R., Osawa, T., Miura, F., Nuarsa, I. W., Ekayanti, N. W., Dharma, I. G. B. S., Adnyana, I. W. S., Arthana, I. W., \& Tanaka, T. (2016). Maritime Continent rainfall variability during the TRMM era: The role of monsoon, topography and El Niño Modoki. Dynamics of Atmospheres and Oceans, 75, 58-77. doi: 10.1016/j.dynatmoce.2016.05.004

Chang, C.P., Wang, Z., McBride, J.L., Liu, C.H. (2005). Annual cycle of southeast Asiamaritime continent rainfall and asymmetric monsoon transition. Journal of Climate, 18, 287-301.

Funk, C., Peterson, P., Landsfeld, M., Pedreros, D., Verdin, J., Shukla, S., Husak, G., Rowland, J., Harrisson, J., Hoell, A., and Michaelsen, J. (2015). The climate hazards infrared precipitation with stations-a new wnvironmental record for monitoring extremes. Scientific data, 2: 150066, doi: 10.1038/sdata.2015.66.

Hidayat, R., Kizu, S. (2010). Influence of the Madden-Julian Oscillation on Indonesian rainfall variability in austral summer. International Journal of Climatology, 30, 181-1825. doi: 10.1002/joc.2005

Hidayat, R. (2016). Modulation of Indonesian Rainfall Variability by the Madden-Julian Oscillation. Procedia Environmental Sciences, 33, 167-177. doi: 10.1016/j.proenv.2016.03.067

Kamimera, H., Mori, S., Yamanaka, M.D., Syamsudin, F. (2012). Modulation of Diurnal Rainfall Cycle by the MaddenJulian Oscillation Based on One-Year Continous Observations with a Meteorological Radar in West Sumatera. Scientific online letters on the atmosphere, 8,111-114. doi:10.2151/SOLA.2012-028

Kiladis, G.N., Wheeler, M.C., Haertel, P.T., Straub, K.H., Roundy, P.E. (2009). Convectively coupled equatorial waves, Reviews of Geophysics., 47, RG2003. doi:10.1029/2008RG000266.

Kim, D., Kim, H., Lee, M.I. (2017). Why does the MJO detour the Maritime Continent during austral summer. Geophysical Research Letters, 44, 2579-2587. doi: 10.1002/2017GL072643

Lee, H. (2015). General Rainfall Patterns in Indonesia and the Potential Impacts of Local Seas on Rainfall Intensity. Water, 7(4), 1751-1768. doi: 10.3390/w7041751

Lestari, S., Hamada, J., Syamsudin, F., Sunaryo, Matsumoto, J., Yamanaka, M.D. (2016). ENSO Influences on Rainfall Extremes around Sulawesi and Maluku Islands in the Eastern Indonesian Maritime Contintent. SOLA, Vol. 12, 37-41, doi:10.2151/sola.2016-008

Madden, R.A., Julian, P.R. (1971). Detection of a 40-50 Day Oscillation in the Zonal Wind in the Tropical Pacific. Journal of the Atmospheric Sciences, 28, 702-708.

Madden, R.A., Julian, P.R. (1972). Description of global-scale circulation cells in tropics with a 40-50 day period. Journal of the Atmospheric Sciences, 29, 1109-1123.

Oh, J.H., Kim, K.Y., Lim, G.H. (2011). Impact of MJO on the diurnal cycle of rainfall over the western Maritime Continent in the austral summer. Climate Dynamics, 38, 1167-1180. doi: 10.1007/s00382-0111237-4

Peatman, S.C., Matthews, A.J., Stevens, D.P. (2014). Propagation of the Madden - Julian Oscillation through the Maritime Continent and scale interaction with the diurnal cycle of precipitation. Quarterly Journal of the Royal Meteorological Society, 140(680), 814-825. doi: 10.1002/qj.2161 
Rauniyar, S.P., Walsh, K.J.E. (2011). Scale Interaction of the Diurnal Cycle of Rainfall over the Maritime Continent and Australia: Influence of the MJO. Journal of Climate, Vol 24(2), 325-348. doi: 10.1175/2010JCLI3673.1

Supari, Tangang, F., Salimun. (2017). ENSO modulation of seasonal rainfall and extremes in Indonesia. Climate Dynamics, 51(7-8), 2559-2580. doi: 10.1007/s00382017-4028-8

Wheeler, M.C., Hendon, H.H. (2004). An AllSeason Real-Time Multivariate MJO Index: Depvelopment of an Indx for Monitoring and Prediction. American meteorology Society, 132, 1917-1931.

Wicaksono, G.B., Hidayat, R. (2016). Extreme Rainfall in Katulampa Associated with the Atmospheric Circulation. Procedia Environmental Sciences, 33(2016), 155166. doi: 10.1016/j.proenv.2016.03.066

Wu, P., Arbain, A.A., Mori, S., Hamada, J.I., Hattori, M., Syamsudin, F., Yamanaka, M. (2013). The effects of an Active Phase of the Madden-Julian Oscillation on the Extreme Precipitation Event over Western Java Island in January 2013. Scientific Online Letters on the Atmosphere, 9, 7983. doi:10.2151/sola.2013-018

Wu, C., Hsu, H. (2009). Topographic Influence on the MJO in the Maritime Continent. Journal of Climate, Vol 22, 5433-5448. DOI: 10.1175/2009JCLI2825.1

Yoneyama, K., Hayati, N. (2015). Rainfall features over the Indonesian Maritime Continent under the different MJO phases. Geophysical Research Abstracts, 17, EGU2015-7520

Zhang, C. (2005). Madden-Julian Oscillation. Reviews of Geophysics, 43, RG2003. doi:10.1029/2004RG000158

Zhang, C., Dong, M. (2004). Seasonality of the Madden-Julian Oscillation. Journal of Climate, 17(16), 3169-3180. doi: $10.1175 / 1520-$

0442(2004)017<3169:SITMO>2.0.CO;2 